\title{
Use of the Salicornia ramosissima for the Phytoextraction of Minerals from the Desalinizer Reject
}

\author{
Karla Alessandra Villela da Silva ${ }^{1}$, José de Paula Oliveira ${ }^{2}$, Eline Waked Ferreira Gomes ${ }^{2}$, \\ Josimar Gurgel Fernandes ${ }^{2}$ and Arminda Saconi Messias ${ }^{1,2 *}$ \\ ${ }^{1}$ Catholic University of Pernambuco - UNICAP, Brazil \\ ${ }^{2}$ Agronomic Institute of Pernambuco - IPA, Brazil \\ *Corresponding author: Arminda Saconi Messias, Catholic University of Pernambuco - UNICAP, Recife, Pernambuco, Brazil
}

\section{ARTICLE INFO}

Received: 蔧 September 11, 2019

Published: 㓞 September 23, 2019

Citation: Karla Alessandra Villela da Silva, José de Paula Oliveira, Eline Waked Ferreira Gomes, Josimar Gurgel Fernandes, Arminda Saconi Messias. Use of the Salicornia ramosissima for the Phytoextraction of Minerals from the Desalinizer Reject. Biomed J Sci \& Tech Res 21(3)-2019. BJSTR. MS.ID.003614.

\begin{abstract}
The objective of this work was to evaluate the absorption of Nitrogen (N), Sodium (Na), Potassium (K), Calcium (Ca) and Magnesium (Mg) by Salicornia ramosissima cultivated in pots with saline soil and submitted to treatments: TA(water) , T1 (desalinizer reject), T2 (desalinizer reject $+7 \mathrm{~g} / \mathrm{NaCl}$ ), $\mathrm{T} 3$ (desalinizer reject $+14 \mathrm{~g} / \mathrm{NaCl}$ ) and $\mathrm{T} 4$ (desalinizer reject $+21 \mathrm{~g} / \mathrm{NaCl}$ ) monitored for four months. The experiment was conducted under greenhouse conditions at the headquarters of the Agronomic Institute of Pernambuco IPA, a completely randomized design with autoclaved and non - autoclaved soil. A dose corresponding to $1.0 \mathrm{~mL} / \mathrm{kg}$ of soil of complete nutrient solution of Hoagland \& Arnon was added every ten weeks. The desalinizer rejects were daily and the results obtained for absorption of the elements by Salicornia showed that with the intermediate dose there was a better absorption mainly of Magnesium (Mg).
\end{abstract}

Keywords: Halophyte; Salicornia; Salinity; Absorption

\section{Introduction}

Salinization is one of the main problems in the semi-arid Pernambuco region. Therefore, producers are obliged to use water with high concentrations of salts for irrigation and food production [1]. In view of the above, desalinators have been implanted with increasing frequensscy in order to obtain potable water. However, despite having advantages, it has as main disadvantage the generation of high salt level waste that can cause environmental problems [2]. Therefore, salt-tolerant halophytes, even beyond the concentrations of seawater, can bring significant benefits to rural communities. However, there is no competition for the use of land or water between profitable conventional attitudes and plants tolerant to high salt content [3,4]. In the work of [5], it was found that halophytes also have the potential to be used for pharmaceuticals, functional foods, and adequate management practices to exploit saline soils and desalinator rejects. As seen, this type of plant has a very diversified use, ranging from the recovery of degraded areas, pollution of biomass, feeding of cattle or human feeding.
Among these species is Salicornia (family Salicornioideae), which presents extensive development in saline areas associated with coastal lines, tidal floodplains and salt lakes. They are distributed worldwide and found on all continents, except Antarctica [6,7]. In order to contribute to the minimization of the negative effects of the inadequate use of the desalinator waste, an experiment was proposed to analyze the absorption of the chemical-bromatological composition $\mathrm{o}$ in the development of Salicornia ramosissima submitted to different levels of salinity.

\section{Materials and Methods}

The experiment was conducted from November 2017 to March 2018, under greenhouse conditions, at the Institute Agronomic of Pernambuco - IPA, Recife, Pernambuco, Brazil. The experimental design was completely randomized, in a $2 \times 2 \times 2 \times 5$ factorial arrangement, corresponding to autoclaved and non-autoclaved soil, inoculated and noninoculated plants, presence and absence 
of [8] nutrient solution (biweekly) and 5 levels of (total control), water (absolute control), desalinator reject (control) and three salinity combinations, whose concentrations were obtained from addition of sodium chloride $(\mathrm{NaCl})$ to the waste, calculated according to Richards (1954): $7 \mathrm{~g}-\mathrm{CE}=12,612 \mu \mathrm{S} / \mathrm{cm}^{2} ; 14 \mathrm{~g}=$ $\mathrm{CE}=13,744 \mu \mathrm{S} / \mathrm{cm}^{2}$ and $21 \mathrm{~g}=\mathrm{CE}=14,746 \mu \mathrm{S} / \mathrm{cm}^{2}$, with three replicates. The soil used in the experiment was collected at the IPA Experimental Station, in the city of. State, Brazil, with the following characteristics: sandy texture, soil density $-1.34 \mathrm{~g} / \mathrm{cm}^{3}, \mathrm{pH}-7.60$, P-209 mg / dm3 and Ca, Mg, Na and K-33.60, 6.00, 12.00 and 0.70 cmolc / $\mathrm{dm}^{3}$ respectively. The average temperature inside the greenhouse during the experiment was $34^{\circ} \mathrm{C}$. According to Köeppen classification, the region presents an As' (Tropical Moist) climate. The mean relative air humidity inside the greenhouse was $56.6 \%$.

The reject used in the experiment was collected in a desalinator located in the city of Riacho das Almas, Pernambuco, Brazil, with the following characteristics: Electrical Conductivity - 10,905 uS/ $\mathrm{cm}^{2}$ at 25으. $\mathrm{pH}-7.0$, and $\mathrm{Ca}, \mathrm{Mg}$, Na and K-139.83, 304.94, 2,760.00 and $22.00 \mathrm{cmolc} / \mathrm{dm}^{3}$ respectively. Salicornia ramosissima $5 \mathrm{~cm}$ cuttings were used in the experiment, which were planted on commercial substrates in 128-cell germination trays for a period of 30 days. After 30 days of rooting, the plants were transferred to the polyethylene pots with $8 \mathrm{~kg}$ of air-dried soil, dewormed, homogenized and sieved in $2 \mathrm{~mm}$ mesh, where $50 \%$ of the soil was sterilized by autoclaving. The inoculation with Arbuscular Mycorrhizal Fungus - FMA was carried out when the rooted plants were transported to the vessels, adding $50 \mathrm{~g}$ of spores the Claroideoglomus etunicatum from the FMA Inoculum Bank of the Laboratory of Soil Microbiology - IPA, where they were kept under refrigeration at $\pm 4^{\circ} \mathrm{C}$.

After four months, the shoot and root were collected, separating them at the height of the plant neck, in paper bags, dried in an air circulation oven at $60^{\circ} \mathrm{C}$ for 72 hours, to determine the dry matter of shoot (MSPA) and root (MSR), the material was ground in a Wiley-type mill, provided with a $42 \mathrm{~mm}$ aperture sieve, by means of nitroperchloric digestion [9], determine the contents of the absorbed elements $(\mathrm{K}, \mathrm{Ca}, \mathrm{Mg}, \mathrm{Na})$ and total nitrogen by the microkjedahl method. A soil sample, too, was collected for complete chemical analysis [10]. The data were submitted to individual and joint statistical analysis, pertinent to the studied variables. The variance was tested by ANOVA (Analysis of Variance) using Minitab statistical software.

\section{Results and Discussion}
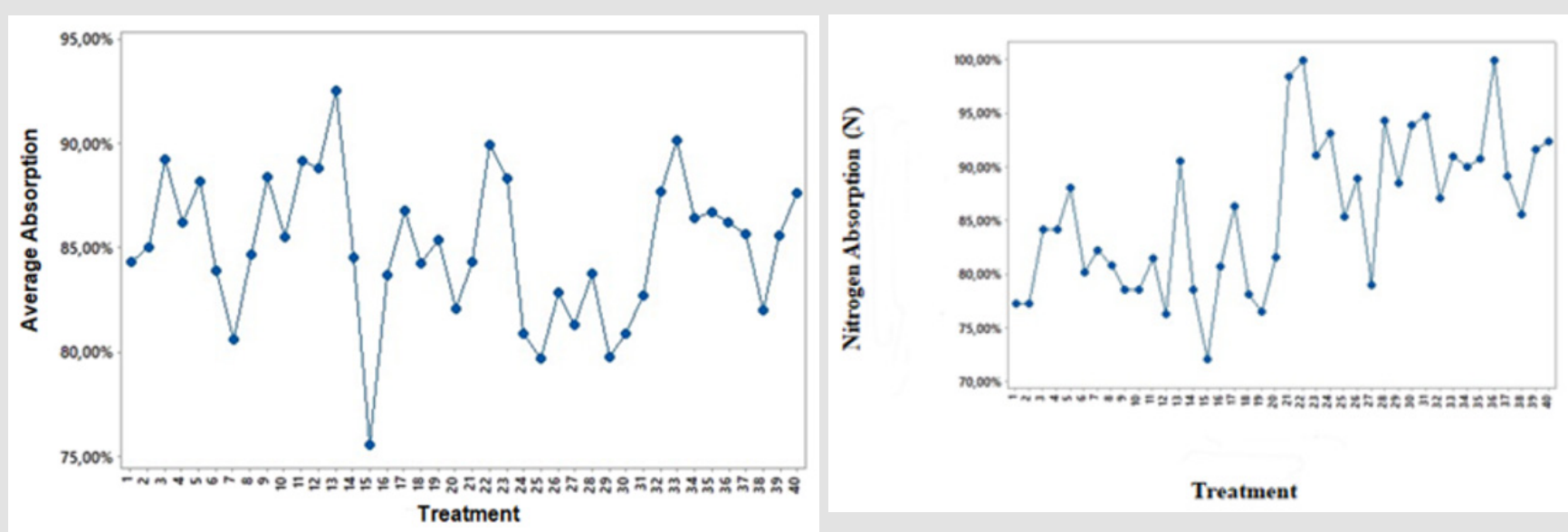

Figure 1: Mean absorption of the chemical elements $(\mathrm{K}, \mathrm{Ca}, \mathrm{Mg}$ and $\mathrm{Na})$ in relation to the treatments used.

Caption: ONLY AUTOCLAVA: 1. Water - 2. Water + FMA - 3. Water + FMA + Solution - 4. Water + Solution - 5.Reject - 6.Reject + FMA - 7.Reject + FMA + Solution - 8. Reject + Solution -9. Rejected +

$1 \mathrm{NaCl}-10$. Reject $+1 \mathrm{NaCl}+\mathrm{FMA}-11$. Reject $+1 \mathrm{NaCl}+\mathrm{FMA}+$ Solution -12. Reject $+1 \mathrm{NaCl}+$ Solution -13. Rejected $+2 \mathrm{NaCl}$ - 14.Rejected $+2 \mathrm{NaCl}+\mathrm{FMA}-15 \cdot$ Rejected $+2 \mathrm{NaCl}+\mathrm{FMA}+$ Solution - 16. Reject $+2 \mathrm{NaCl}+$ Solution $-17 \cdot$ Reject $+3 \mathrm{NaCl}-$ 18. Reject $+3 \mathrm{NaCl}+\mathrm{FMA}-19 \cdot$ Reject $+3 \mathrm{NaCl}+\mathrm{FMA}+$ Solution -20 . Reject $+3 \mathrm{NaCl}+$ Solution .

ONLY NO AUTOCLAVA: 21. Water - 22. Water + FMA - 23. Water + FMA + Solution - 24. Water + Solution - 25.Rejection 26. Rejection + FMA - 27.Rejection + FMA + Solution - 28. Reject+ Solution 29. Reject $+1 \mathrm{NaCl}+$ Solution -30 . Reject_ $1 \mathrm{NaCl}+$ FMA - 31. Reject $+1 \mathrm{NaCl}+\mathrm{FMA}+$ Solution -32 . Reject $+1 \mathrm{NaCl}+$ Solution -33 . Reject $+2 \mathrm{NaCl}-34$. Reject $+2 \mathrm{NaCl}+\mathrm{FMA}-35$. Rejection $+2 \mathrm{NaCl}+\mathrm{FMA}+$ Solution $-36 \cdot$ Rejected $+2 \mathrm{NaCl}+$ Solution $-37 \cdot$ Rejected $+3 \mathrm{NaCl}-38 \cdot \mathrm{Rejected}+3 \mathrm{NaCl}+\mathrm{FMA}-$ 39. Rejected $+3 \mathrm{NaCl}+\mathrm{FMA}+$ Solution -40 . Rejected $+3 \mathrm{NaCl}+$ Solution .

The treatment with a reject plus $14 \mathrm{~g}$ of $\mathrm{NaCl}$ (S2) was the one that best favored the absorption of $\mathrm{Na}, \mathrm{K}, \mathrm{Ca}, \mathrm{Mg}$ and $\mathrm{N}$ when the autoclated soil was used, in the absence of nutrient solution and the fungus Claroideoglomus etunicatum (Figure 1) [11]. working with seedlings of Spondias tuberosa in nutrient solution, with different levels of $\mathrm{NaCl}$, under greenhouse conditions, perceived that the low concentrations of $\mathrm{NaCl}$ favored the presence of $\mathrm{Na}$ in the roots. In the absence of a nutrient solution and the fungus Claroideoglomus 
etunicatum (Figure 1), the treatment with reject plus $14 \mathrm{~g}$ of $\mathrm{NaCl}$ (S2) with autoclaved soil favored $\mathrm{Na}, \mathrm{K}, \mathrm{Ca}, \mathrm{Mg}$ and $\mathrm{N}$ absorption [11]. working with umbuzeiro seedlings in nutrient solution, with different levels of $\mathrm{NaCl}$. Under greenhouse conditions, the low concentrations of $\mathrm{NaCl}$ favored the presence of $\mathrm{Na}$ in the roots, translocating a small amount to the aerial part and that $\mathrm{N}$ and $\mathrm{Ca}$ were few significant in the absorption by the umbuzeiro with the increase of $\mathrm{NaCl}$ concentration.
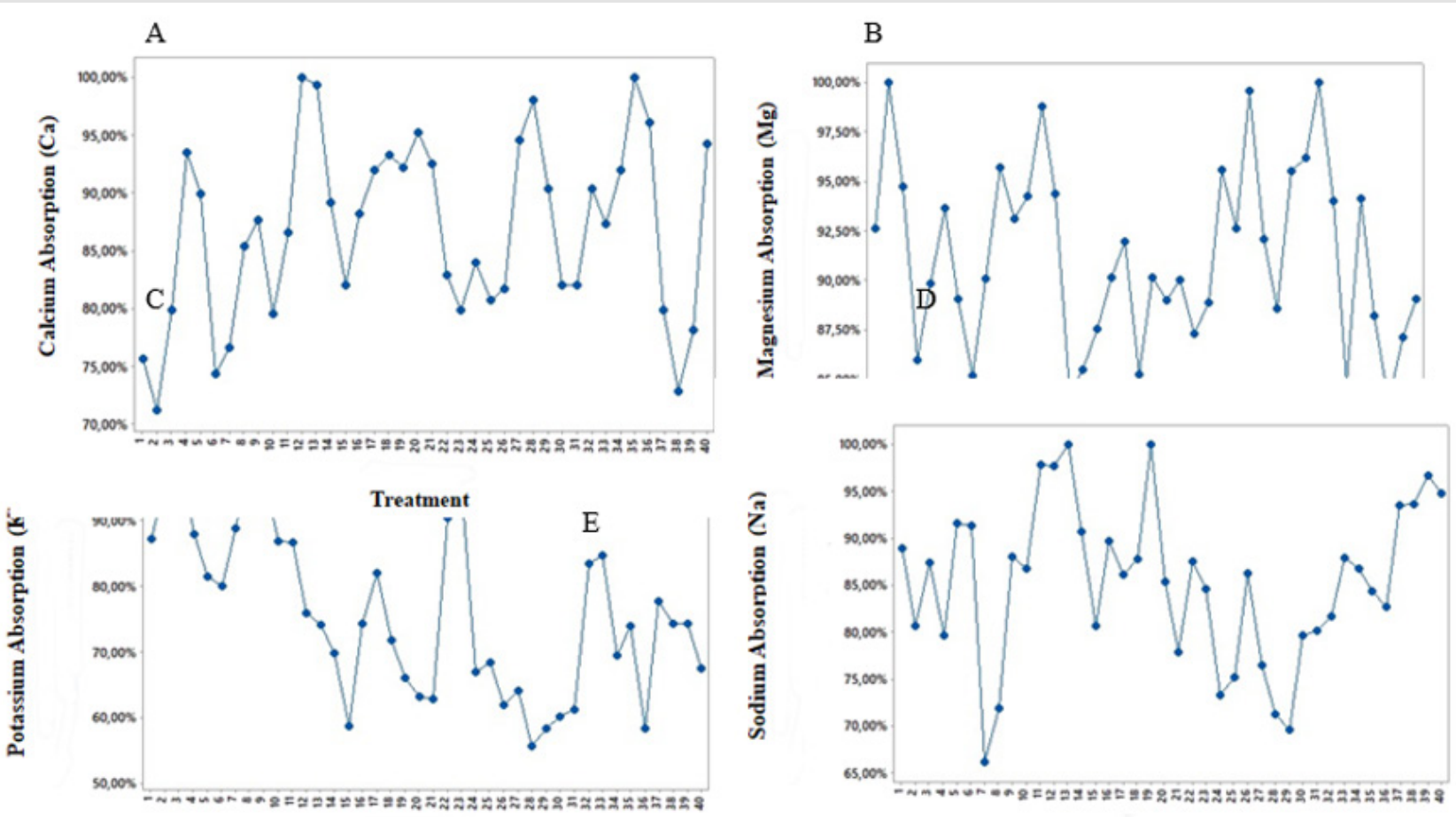

Treatment

Figure 2: Nutritional Analysis of Salicornia ramosissima.

Caption: ONLY AUTOCLAVA: 1. Water - 2. Water + FMA - 3. Water + FMA + Solution - 4. Water + Solution - 5. Reject - 6.Reject + FMA - 7.Reject + FMA + Solution - 8. Reject + Solution -9. Rejected + $1 \mathrm{NaCl}-10$. Reject+ 1NaCl+ FMA - 11. Reject+ 1NaCl+ FMA + Solution -12. Reject $+1 \mathrm{NaCl}+$ Solution -13 . Rejected $+2 \mathrm{NaCl}-14$. Rejected $+2 \mathrm{NaCl}+\mathrm{FMA}-15 . \mathrm{Rejected}+2 \mathrm{NaCl}+$ FMA+ Solution $-16 \cdot$ Reject $+2 \mathrm{NaCl}+$ Solution $-17 \cdot$ Reject $+3 \mathrm{NaCl}-18 \cdot$ Reject $+3 \mathrm{NaCl}+\mathrm{FMA}-19 \cdot \operatorname{Reject}+3 \mathrm{NaCl}+\mathrm{FMA}+$ Solution -20 . Reject $+3 \mathrm{NaCl}+$ Solution.

ONLY NO AUTOCLAVA: 21. Water - 22. Water + FMA - 23. Water + FMA + Solution - 24. Water + Solution - 25. Rejection 26. Rejection + FMA - 27.Rejection + FMA + Solution - 28. Reject+ Solution 29. Reject $+1 \mathrm{NaCl}+$ Solution -30. Reject_ $1 \mathrm{NaCl}+$ FMA -31 . Reject $+1 \mathrm{NaCl}+\mathrm{FMA}+$ Solution -32 . Reject+ $1 \mathrm{NaCl}+$ Solution -33 . Reject $+2 \mathrm{NaCl}-34$. Reject $+2 \mathrm{NaCl}+\mathrm{FMA}-35$. Rejection $+2 \mathrm{NaCl}+\mathrm{FMA}+$ Solution -36 . Rejected $+2 \mathrm{NaCl}+$ Solution $-37 \cdot$ Rejected $+3 \mathrm{NaCl}-38 \cdot \mathrm{Rejected}+3 \mathrm{NaCl}+\mathrm{FMA}-$ 39. Rejected $+3 \mathrm{NaCl}+\mathrm{FMA}+$ Solution -40 . Rejected $+3 \mathrm{NaCl}+$ Solution.

Figure 2A, 2B, 2C, 2D and 2E present individualized information on the absorption of the nutritional composition of the plant with all the treatments used, indicating that Magnesium was the element most absorbed by Salicornia ramosissima [12]. observed that $\mathrm{Na}$ absorbed by Atriplex was higher than those of $\mathrm{Ca}, \mathrm{Mg}$ and $\mathrm{K}$ when grown in greenhouse on saline-sodium soil [13]. in experiment with cassava, observed that, in the case of magnesium, the highest levels were also observed in the treatments that received saline water, which provided greater moisture in the soil, which facilitates the absorption of this ion.

\section{Conclusion}

In view of the obtained results, it is concluded that the bromatological composition of Salicornia ramosissima was not affected by the increase of salinity of irrigation water. The intermediate dose ( $\mathrm{S} 2$ - desalinizer reject plus $14 \mathrm{~g} \mathrm{NaCl}$ ) showed a better absorption mainly of magnesium. High salinity (S3 desalinizer reject plus $21 \mathrm{~g} \mathrm{NaCl}$ ) reduces the growth of Salicornia ramosissima. The addition of nutrient solution and FMA is not significant for the absorption of the determined elements $(\mathrm{N}, \mathrm{Na}, \mathrm{K}$, $\mathrm{Ca}$ and $\mathrm{Mg}$ ). The Salicornia was very promising as a phytoextratora.

\section{Acknowledgement}

The authors are grateful to the Coordination of Improvement of Higher Education Personnel (CAPES) for the master's scholarship, to the Foundation for the Support of Science and Technology of the State of Pernambuco (FACEPE) for the aid search, to the Agronomic Institute of Pernambuco (IPA) for the space physicist, for the Universitas Consortium for the research aid and to the Catholic University of Pernambuco, for the support in the experiment. 


\section{Conflicts of Interest}

The authors declare that they have no conflicts of interests.

\section{References}

1. Ribeiro PHP, Hans RAR, Uyeda CA, Teixeira MB (2016) Growth rate and yield of sunflower irrigated with saline water under nitrogen doses. Irriga 1(1): 233-247.

2. Ribeiro L, Sanches Pagliarussi M, Ribeiro J (2016) Reuse of permeate and wastewater from a reverse osmosis water treatment plant from a hospital hemodialysis unit. Brazilian J Biosystems Engineering 10(3): 259-272.

3. Akinshina N, Azizov A, Karasyova T, Klose E (2016) On the issue of halophytes as energy plants in saline environment. Biomass and Bioenergy 91: 306-311.

4. Gunning D (2016) Cultivating Salicornia europaea (Marsh Samphire) Dublin, Ireland: Irish Sea Fisheries Board pp. 92.

5. Buhmann AK, Wallerb BW, Papenbrocka J (2015) Optimization of culturing conditions and selection of species for the use of halophytes as biofilter for nutrient-rich saline water. Agricultural Water Management 149:102-114

6. Marasco R, Mapelli F, Rolli E, Mosqueira MJ, Fusi M, et al. (2016) Salicornia strobilacea (Synonym of Halocnemum strobilaceum) grown

\section{ISSN: 2574-1241}

DOI: 10.26717/BJSTR.2019.21.003614

Arminda Saconi Messias. Biomed J Sci \& Tech Res

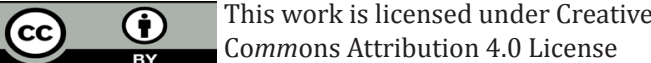

Submission Link: https://biomedres.us/submit-manuscript.php under different tidal regimes selects rhizosphere bacteria capable of promoting plant growth. Frontiers in Microbiology 7: 1286.

7. Patel S (2016) Salicornia: evaluating the halophytic extremophile as a food and a pharmaceutical candidate. Biotech, 6(1):1-10.

8. Hoagland DR, Arnon DI (1950) The waterculture method for growing plants without soil - CA: Agric. Exp Stn, Univ of California. Berkeley.

9. (1999) Embarrass. Brazilian agricultural research company. Brazilian soil classification system. Brasilia: Embrapa Communication for Technology Transfer pp. 412.

10. (1997) Embrapa. Brazilian Agricultural Research Company. Manual of soil analysis methods. Rio de Janeiro pp. 182

11. Neves OSC, Carvalho JG, Rodrigues CR (2004) Growth and mineral nutrition of umbuzeiro (Spondias tuberosa Arr. Cam.) Seedlings submitted to salinity levels in nutrient solution. Science and Agrotechnology 28(5): 997-1006.

12. Souza ER, Freire MBGS, Nascimento CWA, Montenegro AAA, Freire FJ, et al. (2011) Phytoextraction of salts by Atriplex nummularia Lindl. under water stress in sodium saline soil. Brazilian J Agri Environ Engineering 15(5): 477-484

13. Holanda Filho RSF, Santos DB, Azevedo CAV, Coelho EF, Lima VL (2011) Saline water on chemical properties of soil and nutritional status of Cassava. Brazilian J Agr Environ Engineering, 15(1): 60-66.

$\begin{array}{ll}\text { BIOMEDICAL } & \text { Assets of Publishing with us } \\ \text { RESEARCHES } & \text { - Global archiving of articles } \\ \text { - Immediate, unrestricted online access } & \text { - Rigorous Peer Review Process } \\ & \text { - Authors Retain Copyrights }\end{array}$

